\title{
Growth performance of native goats fed diets containing different levels of energy ${ }^{1}$
}

\author{
Lígia Maria Gomes Barreto², Ariosvaldo Nunes de Medeiros ${ }^{3}$, Ângela Maria Vieira Batista 4 , \\ Gherman Garcia Leal de Araújo ${ }^{5}$, Dermeval Araújo Furtado ${ }^{6}$, Ana Cristina Chacon Lisboa ${ }^{2}$, \\ Jória Leilane de Albuquerque Paulo², Aldivan Rodrigues Alves ${ }^{2}$
}

\author{
1 Project financed by CNPq/CAPES. \\ 2 Programa de Pós-graduação em Zootecnia/CCA/UFPB - Areia-PB. \\ ${ }^{3}$ Departamento de Zootecnia/CCA/UFPB - Areia-PB. \\ ${ }^{4}$ Departamento de Zootecnia/UFRPE - Recife-PE. \\ 5 CPATSA/Embrapa Semiárido - Petrolina-PE. \\ ${ }^{6}$ Unidade Acadêmica de Engenharia Agrícola/UFCG - Campina Grande-PB.
}

ABSTRACT - Castrated male goats $(n=40)$ of the Moxotó $(n=20)$ and Canindé $(n=20)$ breeds with an average weight of $15.3 \mathrm{~kg}$ were studied to determine intake, nutrient digestibility and weight gain for two diets with different energy levels. The experiment utilized a $2 \times 2$ factorial arrangement (two breeds and two diets), in which goats were randomly allocated. A diet of low energy density and a forage:concentrate ratio of 70:30 was utilized along with a diet of high energy density and a forage:concentrate ratio of 35:64. To determine the nutrient intake and digestibility, at the end of the experiment, goats were kept in metabolism cages for a period of 15 days. Weighing of the goats was conducted weekly over a period of 90 days. The goats that were fed a diet of high energy density displayed significantly increased consumption of metabolic fractions, with the exception of dry matter and neutral detergent fiber, when compared with those fed a diet of low energy density. The lack of difference in dry matter and neutral detergent fiber intake indicated that goats have a high digestive capacity for the diet containing a greater quantity of Maniçoba hay. Weight gain was significantly greater for those on the diet of greater energy density. Among the breeds, Canindé goats recorded the highest average consumption and weight gain. Coefficients of digestibility were significantly greater for the more energy dense diet, with no difference between breeds. Regardless of diet, the Canindé breed shows greater weight gain than the Moxotó breed.

Key Words: Canindé, Maniçoba hay, Moxotó, nutritional value, semi-arid

\section{Introduction}

The northeast region of Brazil covers an area of 166.2 million hectares, of which 95.2 million (57\%) are located in a semi-arid zone, an area that has a high potential for livestock farming, particularly for small ruminants. The goat population of the northeast $(9,164,421$ animals) corresponds to $90.6 \%$ of the national goat population (IBGE, 2009) excluding native goats, due to their positive adaptation to the semiarid ecosystems, which is strongly influenced by their eating habits.

According to research of Oliveira et al. (2004) and Ribeiro et al. (2004) research, goats, along with other domestic animals, were brought from the Iberian Peninsula to Brazil during the colonial period. After hundreds of years of natural selection occurring over several generations, the modern day ancestors of those animals acquired the ability to survive and flourish in the semi-arid climate. Currently, there are a number of different breeds which exhibit similar characteristics, such as small size, short hair, small ears and low milk production, which differ almost solely by the color of the coat.

Energy is the greatest requirement of animals, and energy used by the animal is derived chiefly from energy ingested and secondly from the mobilization and catabolism of bodily reserves (Morand-Fehr \& Doreau, 2001). Under conditions of high ambient temperature, the animal develops mechanisms to regulate dietary intake to reduce heat production, needing the provision of a diet of high energy density to prevent a decrease in performance and production. In contrast to this, Misra \& Singh (2002) emphasised that goats are well adapted to semi-arid areas, and are not known to reduce food intake, possibly due to climate-related stress having a weaker impact, and having less of a limiting effect on production. This highlights the need to study the native goats in the northeast region of Brazil, since there is a paucity of studies relating to the performance of these breeds, which are demonstrably important to the cultural and economic spheres of the region. 
Therefore, the objective of this study was to assess the intake, digestibility and weight gain of feedlot Canindé and Moxotó goats, under the influence of two diets of different energy content.

\section{Material and Methods}

The study was conducted at the Center for Research of Small Ruminants of the Experimental Station, at the Universidade Federal da Paraíba, located in São João do Cariri, Paraíba, Brazil. The local climate is classified as Bsh: hot and semi-arid, according to the Köppen classification. During the experimental period, from August to November 2007, average daily temperatures of $28^{\circ} \mathrm{C}$, maximum and minimum temperatures of $28^{\circ} \mathrm{C}$ and $21^{\circ} \mathrm{C}$, respectively, relative humidity of $57 \%$ and a total rainfall of $33.8 \mathrm{~mm}$ were recorded (Meteorological Station of the Universidade Federal de Campina Grande/Basin College, 2007).

Castrated male goats $(n=40)$ with an average age of four months, of the Moxotó $(\mathrm{n}=20)$ and Canindé $(\mathrm{n}=20)$ breeds with average body weights (BW) of $15.29 \mathrm{~kg}( \pm 1.76)$ and $15.312 \mathrm{~kg}( \pm 1.94)$, respectively, were utilized to determine nutrient intake and weight gain performance between the low and high energy dense diets. To determine digestibility, 20 animals, 10 of each breed, were randomly chosen and included within the study.

These animals were disinfested and randomly distributed to trial groups according to breed and energy content of the diet. The animals were housed in an open shed, of east-to-west orientation, with a roof of ceramic tiles, and a dirt floor. The shed contained individual pens, each one having an area of $3.75 \mathrm{~m}^{2}$, equipped with a feeder and drinker.

The diets fed to animals were composed of Maniçoba hay (Manihot sp) and a concentrate containing corn meal, soybean meal, sugar cane molasses and a mineral supplement (Table 1). The Maniçoba used for making hay was harvested from plants in the vegetative stage of flowering and fruiting, at their natural habitat in the Caatinga ecoregion of northeastern Brazil.

The diets were formulated according to the NRC (1981), in order to provide an average daily gain of $120 \mathrm{~g}$ (low energy) and $165 \mathrm{~g}$ (high energy) for animals with a body weight of $15 \mathrm{~kg}$ (Table 2).

Animals were fed twice daily, at $7 \mathrm{~h}$ and at $15 \mathrm{~h}$, with a daily adjustment of intake to allow for $20 \%$ surplus. Water was provided ad libitum and was distributed over eight buckets at differing locations within the shed. Intake was quantified daily during the five-day period in which samples were collected for the digestibility trial. Water was weighed using a precision balance at the moment it was supplied, and was weighed 24 hours later, in order to calculate the intake, excluding losses from evaporation over the 24-hour period.

The digestibility trial was conducted at the end of each 15-day experimental periods, of which 10 days were for adaptation of the animals to the cages and five days for the collection of samples. All animals were weighed before and after the digestibility trial. In the morning before feeding, the average BW of Moxotó and Canindé goats that consumed the high energy feed were $20.15 \mathrm{~kg}$ and $22.30 \mathrm{~kg}$, respectively, whilst the average BW of Moxotó and Canindé goats that consumed the low energy feed were $16.40 \mathrm{~kg}$ and $18.19 \mathrm{~kg}$, respectively. The animals were randomly assigned to metabolism cages for testing, which contained a feeder, a drinker and a device to separately collect urine and feces. A cage was placed inside the pen of each animal that was evaluated, to allow all animals to be cared for.

To collect urine, a polythene hose was coupled to a rubber funnel attached to the belly of the animal, to avoid contamination of the urine. A plastic bottle was placed at the end of the hose to collect the urine excreted, which contained $100 \mathrm{~mL}$ of $\mathrm{H}_{2} \mathrm{SO}_{4}$ at a concentration of $20 \mathrm{~mL} / 100 \mathrm{~mL}$, in order to preserve the nitrogen in the urine and to acidify the sample and prevent microbial proliferation.

Aliquots of $20 \%$ of the total surplus food, feces and urine produced were collected daily, placed into plastic bags and stored at $-20^{\circ} \mathrm{C}$ for subsequent qualitative chemical analysis.

Table 1 - Nutritional composition of the ingredients of the experimental diets

\begin{tabular}{|c|c|c|c|c|}
\hline Item $(\mathrm{g} / \mathrm{kg})$ & Maniçoba hay & Corn meal ${ }^{1}$ & Soybean meal & Sugar cane molasses \\
\hline Dry matter & 861.3 & 833.3 & 847.8 & 899.4 \\
\hline Ash & 65.0 & 25.3 & 66.4 & 266.9 \\
\hline Protein & 73.4 & 91.6 & 446.4 & 29.4 \\
\hline Lipids & 24.7 & 105.8 & 9.40 & 12.0 \\
\hline Neutral detergent fiber for ap & 648.5 & 309.4 & 165.5 & - \\
\hline Acid detergent fiber & 512.1 & 74.6 & 105.4 & - \\
\hline Non-fibrous carbohydrates & 188.4 & 467.9 & 260.7 & 691.7 \\
\hline
\end{tabular}

${ }^{1}$ Byproduct from the fabrication of cornflakes.

ap - corrected for ash and protein. 
Table 2 - Chemical-bromatological composition of the experimental diets

\begin{tabular}{lcc}
\hline Ingredient (g/kg DM) & \multicolumn{2}{c}{ Levels of energy } \\
\cline { 2 - 3 } & Low & High \\
\hline Corn meal & 210.0 & 570.0 \\
Soybean meal & 60.0 & 50.0 \\
Sugar cane molasses & 10.0 & 10.0 \\
Mineral supplement & 10.0 & 10.0 \\
Limestone & 10.0 & 10.0 \\
Maniçoba hay & 700.0 & 350.0 \\
Chemical composition (g/kg DM) & \multicolumn{2}{c}{ (calculated) } \\
Dry matter & 868.1 & 864.5 \\
Protein & 101.5 & 108.1 \\
Lipids & 48.5 & 78.6 \\
Neutral detergent fiber ap & 544.6 & 448.2 \\
Acid detergent fiber & 411.6 & 256.4 \\
Non-fibrous carbohydrates & 212.2 & 287.9 \\
Energy value & \multicolumn{2}{c}{ Mcal/kg } \\
Metabolizable energy & 2.24 & 2.70 \\
\hline DM - dry matter; ap - corrected for ash and protein.
\end{tabular}

Chemical-bromatological analysis was performed at the Laboratory of Animal Nutrition, Center of Agrarian Sciences, Universidade Federal da Paraíba. Dry matter (DM), crude protein (CP) and ether extract (EE) were determined according to the AOAC (1990). Neutral detergent fiber (NDF) and acid detergent fiber (ADF) were determined through the use of an $\mathrm{ANKOM}^{220}{ }^{\circledR}$ according to the methodology described by the Ankom Technology Corporation, but utilising TNT (non-woven fabric) bags of $100 \mathrm{~g} / \mathrm{m}^{2}$ weight. Samples of NDF were corrected for ash and protein, with ash calculated through the incineration of neutral detergent insoluble fiber in at $600{ }^{\circ} \mathrm{C}$ for four hours, and protein calculated from the neutral detergent insoluble protein in (NDIP).

Non-fibrous carbohydrates (NFC) were calculated according to Detmann \& Valadares Filho (2010) as: NFC (\%) $=100$ - \%MM - \%EE - \%NDF $\mathrm{AP}$ - \%CP.

To quantify the digestibility of DM, OM, CP, EE, NDF and NFC, all feces were collected, and the amount excreted by each animal over the five-day period was recorded. Samples from every day of collection for each animal were homogenized and an aliquot of $30 \%$ was obtained in order to provide a sample for analysis. Samples were placed in individually identifiable plastic bags and stored at $-20^{\circ} \mathrm{C}$.

Weighing of the animals was conducted weekly, always before the morning feeding, using a digital scale for greater accuracy.

The experimental design was completely randomized within a $2 \times 2$ factorial arrangement (two breeds by two levels of dietary energy content), with 10 repetitions per treatment, totalling 40 data packets for the assessment of intake and performance, and five repetitions per treatment, providing 20 data packets for the assessment of digestibility. Data were evaluated through the analysis of variance, in which $\alpha=0.05$.

\section{Results and Discussion}

Dry matter intake (kg, g/kg of BW and g/ $\mathrm{BW}^{0.75}$ ) was found to have a significant effect solely due to breed, regardless of the energy density of the diet or the amount of Maniçoba hay present in the diet that was consumed. Canindé goats consumed $0.69 \mathrm{~kg}$ of BW, which corresponds to $38.1 \mathrm{~g} / \mathrm{kg} \mathrm{BW}$ and $78.58 \mathrm{~g} / \mathrm{BW}^{0.75}$, which was greater than the intake value of $0.58 \mathrm{~kg} \mathrm{BW}, 34.4 \mathrm{~g} / \mathrm{kg} \mathrm{BW}$ and $69.64 \mathrm{~g} / \mathrm{BW}^{0.75}(\mathrm{P}=0.005)$ displayed by Moxotó goats. These differences in DM intake reflect the higher body weight of the Canindé when compared with the Moxotó breed (Table 3).

In this study, no significant effect of forage:concentrate ratios on intake was found, which was potentially due to the high digestive capacity of goats for diets containing large amounts of roughage for both breeds. As the diet was supplied as a complete feed, the selective effect may have been reduced, allowing for a similar intake, regardless of the amount of Maniçoba hay in it.

The average daily intake observed $(0.645 \mathrm{~kg} /$ day $)$ was greater than $0.48 \mathrm{~kg}$ of DM, which was recommended by the NRC (1981) for animals with a BW of $15 \mathrm{~kg}$ for a gain of $100 \mathrm{~g} /$ day. Average daily intake was similar to that recommended by the NRC (2007) for native animals in development with $15 \mathrm{~kg} \mathrm{BW}$, with an intake of $0.54 \mathrm{~kg}$ DM and $35.9 \mathrm{~g} / \mathrm{kg} \mathrm{BW}$, whilst for animals with BW of $20 \mathrm{~kg}$, daily intake should be 0.62 and $31 \mathrm{~g} / \mathrm{kg} \mathrm{BW}$.

Ribeiro et al. (2006) studied similar breeds of goats of similar age and weight, and reported a daily intake of $0.70 \mathrm{~kg} \mathrm{DM} /$ day, which corresponds to $35.6 \mathrm{~g} / \mathrm{kg}$ BW for animals fed ad libitum, findings which were similar to those of this study.

According to Chizzotti et al. (2005), it is important to determine the level of intake by the animal, from which the nutrients available for maintenance and production can be ascertained. It was also shown that high volume feeds have low ruminal degradation rates, slower rates of passage and digestion, leading to a greater rumen fill and reducing DM intake, contrary to the findings of the present study.

Organic matter (OM) intake and $\mathrm{CP}$ in kg/day differed according to race and type of diet offered; however no significant interaction was discovered between these variables. The average intake of CP (g/day) for the Moxotó and Canindé breeds was $75 \mathrm{~g}$ and 85 g, respectively, and 
$75 \mathrm{~g}$ and $85 \mathrm{~g}$ for the low- and high-energy-density diets, respectively. Although the diets were iso-nitrogenous, animals that consumed the high energy diet ingested $10 \mathrm{~g}$ more CP, due to the lower forage:concentrate ratio (35:65), which could enable a higher ingestion of protein-rich foods (Table 3).

The amounts of CP ingested by the animals met the requirements recommended by the NRCs (1981 and 2007), which recommended an intake, for growing animals with a BW of $20 \mathrm{~kg}$, of $66 \mathrm{~g} /$ day and $86 \mathrm{~g} /$ day, respectively, to enable a gain of $100 \mathrm{~g} / \mathrm{day}$.

The ether extract (EE) intake ( $\mathrm{kg} /$ day), total digestible nutrients (TDN) (kg/day, g/kg BW and g/BW $\left.{ }^{0.75}\right)$ and $\mathrm{ME}$ (Mcal/day and $\mathrm{kcal} / \mathrm{BW}^{0.75}$ ), were significantly influenced by the breed and the diet consumed. For all of these parameters, it was found that the Canindé goat breed displayed the highest average intake, whereas the high energy diet was consumed in greater quantities for both breeds (Table 3).

Neutral detergent fiber intake (NDFi) (kg/day) was significantly influenced by breed $(\mathrm{P}=0.006)$, with the Canindé displaying the highest consumption (Table 3). $\mathrm{NDFi}$ (g/kg BW) showed no significant correlation to breed $(\mathrm{P}=0.025)$ and to diet $(\mathrm{P}=0.001)$, averaging $19.7 \mathrm{~g} / \mathrm{kg} \mathrm{BW}$ for Moxotó and $21.5 \mathrm{~g} / \mathrm{kg}$ BW for Canindé. NDFi (g/kg BW) was not significantly affected by dietary energy level
(22.1 g/kg BW and $19.2 \mathrm{~g} / \mathrm{kg}$ BW for the low and high energy diets, respectively). The less energy dense diet exhibited a greater NDF percentage, which may explain the slightly higher consumption of this dietary fraction (Table 4).

Results from this study indicate that the dry matter intake (DMi) did not differ between diets for all forms over which it was expressed (kg/day, g/day BW or $\left.\mathrm{g} / \mathrm{BW}^{0.75}\right)$, although averages appeared lower for the low energy diet. Similarly, neutral detergent fiber intake (NDFi, kg/day) did not differ between diets. However, the Canindé breed consumed more DM and NDF than the Moxotó, regardless of the diet offered, which may be due to the higher BW exhibited by the breed.

It is possible that this occurrence is related to the peculiarities exhibited by the native breeds and, due to the dearth of research on the matter, the interaction between DMi and NDF cannot be sufficiently distinguished, providing an opportunity for greater research into this.

According to Barreto et al. (2011), these two breeds of goat have a high selective capacity, and even when diets are fed in a complete form of ration, they are able to select the more tender food, which promotes greater digestive efficiency. This phenomenon may explain the lack of a significant difference for the NDF intake across the different diets, despite the lower energy diet containing much more Maniçoba hay, which contains 648.5 g of NDF per kg DM.

Table 3 - Nutrient intake and metabolizable energy, according to breed of goat and energy level of the diet

\begin{tabular}{|c|c|c|c|c|c|c|c|c|}
\hline \multirow[t]{2}{*}{ Intake } & \multicolumn{2}{|c|}{ Moxotó } & \multicolumn{2}{|c|}{ Canindé } & \multirow[t]{2}{*}{ CV (\%) } & \multicolumn{3}{|c|}{$\mathrm{P}$ value } \\
\hline & Low & High & Low & High & & Breed & Diet & $\mathrm{B} \times \mathrm{D}$ \\
\hline Dry matter (kg/day) & 0.554 & 0.611 & 0.654 & 0.732 & 18.3 & 0.005 & 0.067 & 0.757 \\
\hline Dry matter (g/kg BW) & 34.382 & 34.330 & 38.415 & 37.786 & 12.6 & 0,014 & 0,813 & 0,845 \\
\hline Dry matter $\left(\mathrm{g} / \mathrm{BW}^{0.75}\right)$ & 68.818 & 70.453 & 77.941 & 79.224 & 13.4 & 0.007 & 0.645 & 0.955 \\
\hline Organic matter (kg/day) & 0.453 & 0.517 & 0.539 & 0.630 & 20.1 & 0.005 & 0.032 & 0.683 \\
\hline Crude protein (kg/day) & 0.066 & 0.076 & 0.079 & 0.092 & 20.4 & 0.007 & 0.028 & 0.921 \\
\hline Ether extract (kg/day) & 0.035 & 0.063 & 0.043 & 0.074 & 18.0 & 0.002 & 0.000 & 0.472 \\
\hline Total digestible nutrients (kg/day) & 0.335 & 0.452 & 0.396 & 0.542 & 18.1 & 0.004 & 0.000 & 0.589 \\
\hline Total digestible nutrients (g/kg BW) & 20.815 & 25.390 & 23.256 & 27.946 & 12.6 & 0.015 & 0.000 & 0.955 \\
\hline Total digestible nutrients $\left(\mathrm{g} / \mathrm{BW}^{0.75}\right)$ & 41.662 & 52.107 & 47.185 & 58.594 & 13.5 & 0.008 & 0.000 & 0.822 \\
\hline Metabolizable energy (Mcal/day) & 1.241 & 1.650 & 1.465 & 1.978 & 18.2 & 0.005 & $<.000$ & 0.573 \\
\hline Metabolizable energy (kcal/BW ${ }^{0.75}$ ) & 154.152 & 190.224 & 174.587 & 213.905 & 13.5 & 0.007 & $<.000$ & 0.836 \\
\hline
\end{tabular}

$\mathrm{CV}$ - coefficient of variation; BW - body weight; $\mathrm{B} \times \mathrm{D}$ - breed $\times$ diet.

Table 4 - Consumption of carbohydrates and water, according to breed of goat and energy level of the diet

\begin{tabular}{|c|c|c|c|c|c|c|c|c|}
\hline \multirow[t]{2}{*}{ Intake } & \multicolumn{2}{|c|}{ Moxotó } & \multicolumn{2}{|c|}{ Canindé } & \multirow[t]{2}{*}{ CV (\%) } & \multicolumn{3}{|c|}{$\mathrm{P}$ value } \\
\hline & Low & High & Low & High & & Breed & Diet & $\mathrm{B} \times \mathrm{D}$ \\
\hline Neutral detergent fiber (kg/day) & 0.340 & 0.327 & 0.393 & 0.387 & 17.0 & 0.006 & 0.557 & 0.858 \\
\hline Neutral detergent fiber (g/kg BW) & 21.136 & 18.335 & 23.079 & 19.985 & 11.7 & 0.025 & 0.001 & 0.845 \\
\hline Non-fibrous carbohydrates (kg/day) & 0.132 & 0.187 & 0.157 & 0.232 & 22.5 & 0.008 & 0.001 & 0.455 \\
\hline Water (L) & 1.573 & 1.55 & 1.48 & 1.55 & 30.4 & 0.765 & 0.878 & 0.745 \\
\hline Water (L/kg DM) & 2.899 & 2.575 & 2.235 & 2.120 & 28.7 & 0.017 & 0.330 & 0.640 \\
\hline
\end{tabular}

CV - coefficient of variation; BW - body weight; DM - dry matter; B $\times$ D - breed $\times$ diet. 
Furthermore, for Araújo et al. (2004), intake is also controlled by the animal ability to reduce the size of the feed, facilitating digestion and providing the basis for a correlation between DMi and NDF when considering fiber fraction rumination. Following the five-century long natural selection process of this species, since its arrival in Brazil, it can be inferred that these animals have developed adaptive mechanisms that give them a greater ability to select food types, combined with good digestive efficiency.

Allen (1996) compiled data from various studies, and noted that fermentation and rates of passage for NDF are lower than for other dietary constituents, and have a greater effect on the filling time than other non-fiber components, and therefore may be used as a chemical indicator for DMi. It can be inferred that the relationship between NDF and DMi for ruminants is inversely proportional, in which a reduction in DMi may occur due to an increase in NDF in the diet. This is in agreement with the theory that a fibrous mass in the rumen-reticulum may act as an inhibitor of the DMi.

Non-fibrous carbodyrate intake (NDFi, kg/day) differed significantly between breeds and diets, with averages of 0.16 and $0.19 \mathrm{~kg} / \mathrm{day}$ for Canindé and Moxotó breeds, respectively, and 0.14 and $0.21 \mathrm{~kg} /$ day for the low and high energy diets, respectively (Table 4).

Total consumption of carbohydrates expressed in kg/day were higher than those recommended by the NRC (1981) for goats in this category, which suggests that the animals possess a large rumen fill capacity, and that the chemicalbromatological composition of the Maniçoba hay differs from that of forage in temperate climates. In addition to this, Misra \& Khub (2002) reported that goats are well adapted to semi-arid areas and do not appear to reduce food intake, potentially due to a lower effect of climate impact upon these animals, as the effects do not appear to limit their production.

Ribeiro et al. (2009) emphasized that the level of food influences the consumption and selective capacity for feedlot Canindé and Moxotó goats, without compromising the composition of the diet ingested.
There was no effect of breed or diet on the average water intake $(\mathrm{L})(\mathrm{P}=0.765$ and $\mathrm{P}=0.878$, respectively $)$. There was no effect observed for breed on the efficiency of water intake (L/kg DM), although Moxotó goats displayed the highest average, and Canindé, the lowest $(2.74 \mathrm{~L} / \mathrm{kg}$ DM and $2.18 \mathrm{~L} / \mathrm{kg} \mathrm{DM}$, respectively). These results reflect the greater DM intake demonstrated by the Canindé breed, which, when paired with similar water intake, led to the lessening of the breed efficiency in water consumption (Table 4).

Sheridan et al. (2000) evaluated the effects of two different energy levels in the diets of Boer goats in South Africa, and discovered that the water intake of these animals was $2.44 \mathrm{~L}$ and $1.97 \mathrm{~L}$, and the efficiency of water intake was $1.82 \mathrm{~L} / \mathrm{kg}$ DM and $1.71 \mathrm{~L} / \mathrm{kg}$ DM for the low and high energy diets, respectively. In contrast to this, results from this study indicate an average water intake of $1.54 \mathrm{~L} /$ day at an efficiency of $2.57 \mathrm{~L} / \mathrm{kg}$ DM and $2.35 \mathrm{~L} / \mathrm{kg}$ DM for the low and high energy diets, respectively. Water intake was not found to be affected by the diet consumed in this study.

These results relating to water intake differ from those observed by Herdt (1993), in which it was reported that diets containing a greater proportion of forage had a greater stimulatory effect on rumination and salivation, alongside with greater dilution of ruminal content, requiring less water intake. By contrast, diets that contain a greater amount of concentrated nutrients do not promote greater rumination, and require greater water intake.

For all coefficients of digestibility, there was no effect of breed, and no evident breed $\times$ diet interaction. However, diet was shown to influence the digestibility of nutritional fractions, with the exception of CP and NDF (Table 5).

The average values for the coefficients of DM apparent digestibility were 0.578 and 0.692 for the low and high energy diets, respectively. This may be due to the lower concentration of easily digestible non-structural carbohydrates in the low energy diet compared with that found in the high energy diet (Table 5). These results are supported by Smith et al. (2007), who studied the inclusion

Table 5 - Coefficients of digestibility for nutritional fractions for Canindé and Moxotó goats fed with diets of two different energy levels

\begin{tabular}{|c|c|c|c|c|c|c|c|c|}
\hline \multirow[t]{2}{*}{ Digestibility } & \multicolumn{2}{|c|}{ Moxotó } & \multicolumn{2}{|c|}{ Canindé } & \multirow[t]{2}{*}{ CV (\%) } & \multicolumn{3}{|c|}{$\mathrm{P}$ value } \\
\hline & Low & High & Low & High & & Breed & Diet & $\mathrm{B} \times \mathrm{D}$ \\
\hline Dry matter & 0.552 & 0.677 & 0.604 & 0.707 & 10.3 & 0.209 & 0.003 & 0.727 \\
\hline Organic matter & 0.596 & 0.698 & 0.651 & 0.722 & 9.1 & 0.194 & 0.009 & 0.599 \\
\hline Crude protein & 0.633 & 0.631 & 0.662 & 0.699 & 10.9 & 0.173 & 0.619 & 0.578 \\
\hline Ether extract & 0.598 & 0.812 & 0.607 & 0.853 & 9.4 & 0.455 & 0.001 & 0.627 \\
\hline Neutral detergent fiber & 0.467 & 0.506 & 0.581 & 0.559 & 16.0 & 0.057 & 0.833 & 0.466 \\
\hline Non-fibrous carbohydrates & 0.858 & 0.892 & 0.846 & 0.901 & 4.4 & 0.938 & 0.022 & 0.569 \\
\hline TDN & 0.601 & 0.732 & 0.616 & 0.758 & 10.6 & 0.484 & 0.002 & 0.929 \\
\hline
\end{tabular}

TDN - total digestible nutrients; CV - coefficient of variation; B $\times$ D - breed $\times$ diet. 
of Maniçoba hay at varying levels within diets for sheep, and recorded DM apparent digestibility averages of 0.575 and 0.652 for levels of $600 \mathrm{~g} / \mathrm{kg}$ DM and $400 \mathrm{~g} / \mathrm{kg}$ DM of hay in the diet, respectively.

In contrast to these findings, Araújo et al. (2009) studied the effect of diet on dairy goats and found DM apparent digestibility averages that varied between 0.596 and 0.508 for diets that included hay in the diets at $300 \mathrm{~g} / \mathrm{kg}$ DM and $600 \mathrm{~g} / \mathrm{kg}$ DM, respectively; findings that appear to be significantly lower than those of this study.

Alves et al. (2003) discovered that the concentration of NDF in the diet is inversely correlated to the level of energy in the diet and digestibility of DM. The authors suggested that the energy value of feeds can be estimated with certainty from the concentrations of NDF, which would prove a simpler and less costly procedure. These results are paralleled within the current study, as DM apparent digestibility and level of dietary energy are found to increase whilst levels of NDF decrease (Table 5).

The mean apparent digestibility of OM was found to be 0.623 and 0.710 for the low and high energy diets, respectively (Table 5). Araújo et al. (2009) utilized a different methodology to estimate the OM apparent digestibility, and discovered a lower mean value of 0.533 the diet containing $600 \mathrm{~g} / \mathrm{kg}$ DM of hay and $2.45 \mathrm{Mcal}$ day/kg DM. The authors hypothesized that the OM apparent digestibility is related to the energy level of the diet (TDN), with the decrease in digestibility being attributable to the lower energy value of the diets containing a greater proportion of hay, a hypothesis supported by the results of this study.

Silva et al. (2007) reported that an increase in the proportion of hay within the diet and a consequent reduction of energy level caused a reduction in the digestibility of nutrients, with the exception of EE. The authors reported values for DM apparent digestibility which are similar to those discovered in this study; however they reported digestibility coefficients for the other nutritional fractions lower than the values found this paper.

In a study conducted on Morada sheep in late pregnancy, França (2006) evaluated the effects of increasing levels of dietary energy and discovered that the apparent digestibility of CP decreased from 0.728 to 0.698 , and the apparent digestibility of EE increased from 0.816 to 0.923 in the diets containing 2.29 and $2.51 \mathrm{Mcal} / \mathrm{kg} \mathrm{DM}$, respectively. These results are higher than those reported in this study, in which average CP apparent digestibility values were 0.648 and 0.665 , and average EE apparent digestibility values of 0.602 and 0.832 were reported for the low and high energy diets, respectively. This phenomenon may be explained by the differences between the diets within the two studies, in which França (2006) utilized a Tifton and cactus forage mixture, of which the latter displays greater properties of digestibility.

The apparent digestibility of NDF was not found to be influenced by dietary energy level (Table 5), which was also reported by Araújo et al. (2009) and França (2006). Contrary to these findings, Alves et al. (2003) and Silva et al. (2007) discovered a reduction in NDF apparent digestibility as dietary energy level increased, and noted that diets high in starch contain more energy and act to depress the ruminal digestibility of the fiber. Apparent digestibility of NFC (DNFC) increased as dietary energy levels increased (Table 5), which echoes the findings of Araújo et al. (2009) and Silva et al. (2007). This finding may be attributed to the greater concentration of fibrous carbohydrates in diets of low energy, which are less digestible. These studies support the conclusions of Alves et al. (2003), who reported that the increase in dietary energy value improved NFC apparent digestibility.

Final body weight (FBW), total gain (TG) and average daily gain (ADG) were influenced by both goat breed and dietary energy level (Table 6).

Overall, the results suggest that the Canindé has greater weight gain performance than the Moxotó breed, potentially as a result of their greater dietary energy intake. The animals began the study weighing an average of $15.22( \pm 1.78) \mathrm{kg}$, and at the conclusion reached average BW of 20.06 and $21.65 \mathrm{~kg}$ (Moxotó and Canindé breeds, respectively). Animals subjected to the low and high energy diets recorded FBW values of 18.77 and $22.88 \mathrm{~kg}$, respectively (Table 6).

Table 6 - Weight gain performance for Canindé and Moxotó goats fed diets of two differing energy levels

\begin{tabular}{|c|c|c|c|c|c|c|c|c|}
\hline \multirow[t]{2}{*}{ Variable } & \multicolumn{2}{|c|}{ Moxotó } & \multicolumn{2}{|c|}{ Canindé } & \multirow[t]{2}{*}{ CV (\%) } & \multicolumn{3}{|c|}{$\mathrm{P}$ value } \\
\hline & Low & High & Low & High & & Breed & Diet & $\mathrm{B} \times \mathrm{D}$ \\
\hline Initial body weigth $(\mathrm{kg})$ & 14.95 & 15.28 & 14.98 & 15.65 & 12.0 & - & - & - \\
\hline Total gain $(\mathrm{kg})$ & 3.07 & 6.63 & 4.48 & 8.20 & 33.9 & 0.021 & 0.000 & 0.894 \\
\hline Average daily gain (g/day) & 34.47 & 74.49 & 50.29 & 92.17 & 33.9 & 0.021 & 0.000 & 0.894 \\
\hline
\end{tabular}

$\mathrm{CV}$ - coefficient of variation; $\mathrm{B} \times \mathrm{D}$ - breed $\times$ diet. 
Average daily gain follows similar patterns to those exhibited by other weight-related variables, with mean values of 55.54 and $71.23 \mathrm{~g} /$ day observed for the Moxotó and Canindé breeds, respectively, and 42.80 and $83.33 \mathrm{~g} /$ day for the low and high energy diets, correspondingly. This represents the same percentage increase observed for TG (Table 6). From these results, it is evident that increasing the dietary energy level led to improved weight gain; however, the animals did not reach the targeted ADG of $120 \mathrm{~g}$ and 165 g recommended by the NRC (1981) when consuming diets containing 2.2 and $2.7 \mathrm{Mcal} \mathrm{ME} / \mathrm{kg} \mathrm{DM}$. These findings may be attributed to the sensitivity displayed by the feedlot animals, which was noticed during the course of the study, and may be reflected in their growth performance.

In a study on sheep with an average initial weight of $16.0 \mathrm{~kg}$, Araújo et al. (2004) found no significant effect of the proportion of Maniçoba hay within the diet, on weight gain, recording an average gain of $44 \mathrm{~g} / \mathrm{kg} / \mathrm{day}$. Despite the study being performed on a different species, the authors reported daily gains that were lower than those recorded in this study. In another study with sheep at rearing, Castro et al. (2007) found the energy level of diet to have an effect of ADG, where the animals gained $261.0 \mathrm{~g} /$ day, from an initial BW average of $16.02 \mathrm{~kg}$.

According to Sheridan et al. (2000), Boer goats displayed no significant difference in ADG when fed diets of low (2.14 Mcal/kg DM) and high energy (2.60 Mcal/kg DM) diets, averaging 0.152 and $0.162 \mathrm{~kg} /$ day, respectively. Mahgoub et al. (2005) studied the effect of dietary energy level on the development of goat breeds native to the semiarid region of Sudan, and reported significant differences in ADG with changes in dietary energy levels. For diets containing 2.07, 2.38 and $2.68 \mathrm{Mcal} / \mathrm{kg}$ DM, ADG values of 48.0, 66.5 and 74.5 g/day, respectively, were observed, similarly to those reported in this research.

\section{Conclusions}

Diets with higher energy content lead to greater intake and growth performance of feedlot Canindé and Moxotó goats. However, Canindé goats, when subjected to the same management conditions of the Moxotó breed, show propensity for greater weight gain.

\section{References}

ALLEN. M.S. Physical constraints on voluntary intake of forages by ruminants. Journal of Animal Science, v.74, p.3063-3075, 1996.

ALVES, K.S.; CARVALHO, F.F.R.; VÉRAS, A.S.C. et al. Níveis de energia em dietas para ovinos Santa Inês: digestibilidade aparente. Revista Brasileira de Zootecnia, v.32, p.1962-1968, 2003.

ASSOCIATION OF OFFICIAL ANALYTICAL CHEMISTS - AOAC Official methods of analysis of AOAC international 14.ed. Washington, DC.: 1990. 1094p.

ARAÚJO, G.G.L.; MOREIRA, J.N.; FERREIRA, M.A. et al. Consumo voluntário e desempenho de ovinos submetidos a dietas contendo diferentes níveis de feno de maniçoba. Revista Ciência Agronômica, v.35, p.123-130, 2004

ARAÚJO, M.J.; MEDEIROS, A.N.; CARVALHO, F.F.R. et al. Consumo e digestibilidade dos nutrientes em cabras da raça Moxotó recebendo dietas com diferentes níveis de feno de maniçoba. Revista Brasileira de Zootecnia, v.38, p.1088-1095, 2009.

BARRETO, L.M.G.; MEDEIROS, A.N.; BATISTA, A.M.V. et al. Comportamento ingestivo de caprinos das raças Moxotó e Canindé em confinamento recebendo dois níveis de energia na dieta. Revista Brasileira de Zootecnia, v.40, p.834-842, 2011.

CASTRO, J.M.C.; SILVA, D.S.; MEDEIROS, A.N. et al. Desempenho de cordeiros Santa Inês alimentados com dietas completas contendo feno de maniçoba. Revista Brasileira de Zootecnia, v.36, p.674-680, 2007.

CHIZZOTTI, M.L.; VALADARES FILHO, S.C.; LEÃO, M.I. et al Casca de algodão em substituição parcial à silagem de capimelefante para novilhos. 1. Consumo, degradabilidade e digestibilidade total e parcial. Revista Brasileira de Zootecnia, v.34, p.2093-2102, 2005.

DETMANN, E.; VALADARES FILHO, S.C. On the estimation of non-fibrous carbohydrates in feeds and diets. Communication. Arquivo Brasileiro de Medicina Veterinária e Zootecnia, v.62, p.980-984, 2010

FRANÇA, S.R.L. Níveis de energia metabolizável para ovelhas Morada Nova, no terço final da gestação. 2006. $55 \mathrm{f}$ Dissertação (Mestrado em Zootecnia) - Universidade Federal da Paraíba, Areia.

HERDT, T. Digestão: Processos fermentativos. In: CUNNINGHAM, J.C. (Ed). Tratado de fisiologia veterinária. Rio de Janeiro: Guanabara Koogan S. A. , 1993. p.222-241.

INSTITUTO BRASILEIRO DE GEOGRAFIA E ESTATÍSTICA IBGE. [2009]. Produção da pecuária municipal. Rio de Janeiro: IBGE, v.37, p.1-55, 2009. Available at: <http:// www.ibge.gov.br/home/estatistica/economia/ppm/2009/ ppm2009.pdf.> Accessed on: July 15, 2011.

MAHGOUB, O.; LU, C.D.; HAMEED, M.S. et al. Performance of Omani goats fed diets containing various metabolizable energy densities. Small Ruminant Research, v.58, p.175-180, 2005.

MISRA, A.K.; SINGH, K. Effect of water deprivation on dry matter intake, nutrient utilization and metabolic water production in goats under semi-arid zone of India. Small Ruminant Research, v.46, p.159-165, 2002.

MORAND-FEHR, P.; DOREAU, M. Ingestion et digestion chez les ruminants soumis à um stress de chaleur. INRA Production Animal, v.14, p.15-27, 2001.

NATIONAL RESEARCH COUNCIL - NRC. Nutrient requirements of domestics animals: nutrient requirement of goats. Washington, D.C.: National Academy Press, 1981. 91p.

NATIONAL RESEARCH COUNCIL - NRC. Nutrient requirements of small ruminants: sheep, goats, cervids and new words camelids. Washington, D.C.: National Academy Press, 2007. $384 p$.

OLIVEIRA, J.C.V.; ROCHA, L.L.; MENEZES, M.P.C. et al. Recursos genéticos existentes e suas características. In: RIBEIRO, M.N.; GOMES FILHO, M.A.; DELGADO BERMEJO, J.V. (Eds.) et al. Conservação de raças caprinas nativas do Brasil: histórico, situação atual e perspectivas. Recife: UFRPE, Imprensa Universitária, 2004. 62p.

RIBEIRO, V.L.; BATISTA, A.M.V.; CARVALHO, F.F.R. et al. Seletividade e composição da dieta ingerida por caprinos 
recebendo alimentação à vontade e restrita. Revista Brasileira de Ciências Agrárias, v.4, p.91-94, 2009.

RIBEIRO, V.L.; BATISTA, A.M.V.; CARVALHO, F.F.R. et al. Comportamento ingestivo de caprinos Moxotó e Canindé submetidos à alimentação à vontade e restrita. Acta Scientiarum Animal Sciences, v.28, p.331-337, 2006.

RIBEIRO, M.N.; OLIVEIRA, J.C.V.; GOMES FILHO, M.A. Antecedentes históricos. In: RIBEIRO, M.N.; GOMES FILHO, M.A.; DELGADO BERMEJO, J.V. et al. (Eds.) Conservação de raças caprinas nativas do Brasil: histórico, situação atual e perspectivas. Recife: UFRPE, Imprensa Universitária, 2004. $62 \mathrm{p}$.

SHERIDAN, R.; FERREIRA, A.V.; HOFFMAN, L.C. et al. Effect of dietary energy level on efficiency of SA Mutton Merino lambs and Boer goat kids under feedlot conditions. South African Journal of Animal Science, v.30, p.122-123, 2000.

SILVA, D.S.; CASTRO, J.M.C.; MEDEIROS, A.N. et al. Feno de maniçoba em dietas para ovinos: consumo de nutrientes, digestibilidade aparente e balanço nitrogenado. Revista Brasileira de Zootecnia, v.36, p.1685-1690, 2007. 